University of Pennsylvania Carey Law School

Penn Law: Legal Scholarship Repository

Faculty Scholarship at Penn Law

1995

\title{
Attorney-Client and Work Product Protection in a Utilitarian World: An Argument for Recomparison
}

\author{
Catherine T. Struve \\ University of Pennsylvania Carey Law School
}

Follow this and additional works at: https://scholarship.law.upenn.edu/faculty_scholarship

Part of the Legal History Commons, Legal Profession Commons, Litigation Commons, and the Privacy Law Commons

\section{Repository Citation}

Struve, Catherine T., "Attorney-Client and Work Product Protection in a Utilitarian World: An Argument for Recomparison" (1995). Faculty Scholarship at Penn Law. 1296.

https://scholarship.law.upenn.edu/faculty_scholarship/1296

This Article is brought to you for free and open access by Penn Law: Legal Scholarship Repository. It has been accepted for inclusion in Faculty Scholarship at Penn Law by an authorized administrator of Penn Law: Legal Scholarship Repository. For more information, please contact PennlawIR@law.upenn.edu. 


\section{ATTORNEY-CLIENT AND WORK PRODUCT PROTECTION IN A UTILITARIAN WORLD: AN ARGUMENT FOR RECOMPARISON}

Attorney-client privilege and work product immunity are closely connected. Both protect litigants, ${ }^{1}$ and both stand in tension with the traditional notion that "the public ... has a right to every man's evidence." In practice, the two protections are even more closely identified, because they are often invoked together to protect identical materials. ${ }^{3}$ Moreover, the utilitarian justifications for the two protections are very similar, as are the critiques of those justifications. ${ }^{4}$ On the other hand, some commentators have argued that the attorney-client privilege rests on a unique rationale for individual (as opposed to organizational) clients, because protection for attorney-client communications safeguards important individual rights. ${ }^{5}$ Such rights-based arguments persisted well into the twentieth century but have since faded from view. ${ }^{6}$

Recently, the American Law Institute (ALI) began work on a Restatement of the Law Governing Lawyers. The tentative drafts of the Restatement discuss both the attorney-client ${ }^{7}$ and work product ${ }^{8}$ protections and incorporate notable innovations, particularly in the area of waiver. ${ }^{9}$ In keeping with the modern trend, the ALI deemphasizes

${ }^{1}$ Both the attorney-client privilege and work product immunity protect litigants during discovery. The attorney-client privilege prevents disclosure of protected communications at trial, as well as beforehand. See Note, Functional Overlap Between the Lawyer and Other Professionals: Its Implications for the Privileged Communications Doctrine, 7I YALE L.J. 1226, 1226 (1962) [hereinafter Overlap]. By contrast, "proponents of work product immunity claim that immunity really conceals nothing because facts are discoverable before trial, and trial strategy (opinion work product) will be disclosed at the trial itself." Elizabeth Thornburg, Rethinking Work Product, 77 VA. L. REv. 1515, I525 (I99I). However, work product protection will sometimes result in the suppression of facts both before and during trial. See Vincent C. Alexander, The Corporate Attorney-Client Privilege: A Study of the Participants, 63 ST; JoHN's L. Rev. I9I, 264 n.220 (1989); Thornburg, supra, at 1555 . Moreover, the great majority of cases are settled or otherwise resolved prior to trial, and disputes settled during discovery "risk a lopsided settlement based on incomplete information because of work product protection." Id. at 1525 .

2 United States v. Bryan, 339 U.S. 323, 331 (r950) (quoting 8 John H. Wigmore, Evidence in Trials at COMmon LaW $\$ 2192$, at 70 (3d ed. 1942$)$ ).

3 See Richard L. Marcus, The Perils of Privilege: Waiver and the Litigator, $84 \mathrm{MrCH}$. L. REV. 1605,1624 (1986).

4 See infra notes $20-3 \mathrm{I}$ and accompanying text.

5 See infra notes $34-40$ and accompanying text.

${ }^{6}$ See infra notes $51-55$ and accompanying text.

7 See Restatement (Third) of the Law Governing Lawyers (Tentative Draft No, 2 , 1989) [hereinafter RestatemENT, 1989 Draft]. Among other topics, the rg89 draft addresses attorney-client privilege, but not work product protection.

8 See Restatement (Third) of the LaW Governing Lawyers (Tentative Draft No. 6, 1993) [hereinafter RESTATEMENT, 1993 Draft]. The 1993 draft covers work product protection, but not attorney-client privilege.

9 Such innovations include the "work product as evidence" waiver. See infra Part II.C. 
rights-oriented rationales for the attorney-client privilege and focuses instead on utilitarian justifications for each protection. However, certain disparities in the ALI's treatment of the two protections illustrate that rights-oriented thinking continues to exert a subtle influence over the treatment of the protections. Part I of this Note sets forth the nature of and traditional justifications for the protections and describes how the rise of the corporate client coincided with the fall of the rights-based argument for the attorney-client privilege. Using the ALI's drafts as a basis for discussion, Part II examines three areas waiver by disclosure, shareholder litigation, and "evidence" waiver in which differences between the treatment of the two protections should now be justified solely on utilitarian grounds.

\section{The Nature of and Justifications for the AtTorney- Client and Work Product Protections}

A typical formulation of the common law ${ }^{10}$ attorney-client privilege has been expressed by the Second Circuit:

(I) [W] here legal advice of any kind is sought (2) from a professional legal advisor in his capacity as such, (3) the communications relating to that purpose, (4) made in confidence (5) by the client, (6) are at his instance permanently protected (7) from disclosure by himself or by the legal advisor, (8) except the protection be waived .... ${ }^{11}$

Work product immunity, a much more recent innovation, is a creature of both case law and code. Rule 26(b)(3) of the Federal Rules of Civil Procedure codifies Hickman v. Taylor, ${ }^{12}$ the first Supreme Court case to recognize protection for attorney work product. ${ }^{13}$ Under Rule 26 (b)(3), work product protection extends to "documents and tangible things ... prepared in anticipation of litigation or for trial by or for [a] party or [a] party's representative." ${ }^{14}$ Although the Rule confines the protection to tangible items, federal common law extends immunity to all work product regardless of the method of discovery. ${ }^{15}$ Work product protection, however, is not absolute and can be partially

10 This Note focuses on federal common law interpretations of the attorney-client and work product protections. For the implications of diversity and federal question jurisdiction for federal courts' analyses of privilege issues, see Garner v. Wolfinbarger, 430 F.2d 1093, 1097-1 100 (5th Cir. 1970).

11 In re Grand Jury Subpoena Duces Tecum Dated September 15, 1983 (Marc Rich \& Co.), 731 F.2d 1032, 1036 (2d Cir. 1984) (quoting United States v. Bein, 728 F.2d 107, 112 (2d Cir. r984) (quoting United States v. Kovel, 296 F.2d g18, 92 I (2d Cir. I961) (quoting 8 JoHN H. Wigmore, EVIdENCE in TRIALS AT COMMON LAW $\$ 2292$, at 554 (John T. McNaughton rev, ed. I96r))); see also United States v. United Shoe Mach. Corp., 89 F. Supp. 357, 358-59 (D. Mass. r950) (providing a similar but more detailed synopsis).

12329 U.S. 495 (1947).

13 See Hickman, 329 U.S. at 5 ro.

14 FED. R, CIV, P. 26(b)(3).

15 See, e.g., Hickman, 329 U.S. at 5 II; Clute v. Davenport Co., I18 F.R.D. 312, 315 (D. Conn. I988). 
pierced in certain circumstances. To obtain disclosure of otherwise protected work product, a party must show "substantial need of the materials in the preparation of the party's case and that the party is unable without undue hardship to obtain the substantial equivalent of the materials by other means." 16 . The fulfillment of these conditions, though, does not completely nullify work product protection. Even when a party demonstrates substantial need and undue hardship, the Rules instruct the court to guard against disclosure of "mental impressions, conclusions, opinions, or legal theories of an attorney or other representative of a party concerning the litigation."17 However, even absent a showing of need and hardship, underlying facts, as in the case of the attorney-client privilege, ${ }^{18}$ are fully discoverable. ${ }^{19}$

The justifications most often advanced for both protections are pragmatic and systemic. According to this view, the attorney-client privilege fosters full disclosure by clients to their attorneys, because the client has no fear that statements made in confidence can be used against her. This openness, in turn, enables attorneys to provide the best possible legal advice. ${ }^{20}$ Optimal legal advice benefits not only the client, but also society, because sound advice conduces to "compliance with the ever growing and increasingly complex body of public law." 21 In addition, proponents of the attorney-client privilege claim that it increases the accuracy of trial results by "enhanc[ing] the quality of legal representation." 22 Similarly, "the [work-product] doctrine is an intensely practical one, grounded in the realities of litigation in our adversary system." 23 In Hickman, the Supreme Court fashioned work product immunity as a zone of privacy ${ }^{24}$ within which lawyers could prepare for trial..$^{25}$ Without work product protection, some fear that the factfinding incentives generated by litigation would evaporate -

16 FED. R. Crv. P. 26(b)(3).

17 Id.

18 See Upjohn Co. v. United States, 449 U.S. 383, 395 (1981).

19 See Hickman, 329 U.S. at 513. The framework for work product protection has been explained in the following way:

Both Hickman and Rule $26(\mathrm{~b})(3)$ envision a hierarchy of protection: ( $\mathrm{I}$ ) facts contained in work product, which are discoverable if a litigant can figure out the right question to ask; (2) ordinary work product, which is discoverable on a showing of substantial need and undue hardship; and $(3)$ opinion work product, which is rarely, if ever, discoverable.

Thornburg, supra note 1 , at 1520 .

20 See, e.g., Fisher v. United States, 425 U.S. 391,403 (1976).

21 In re Grand Jury Subpoena Duces Tecum Dated September 15, I983 (Marc Rich \& Co.), 73I F.2d 1032, 1037 (2d Cir, 1984) (citing Upjohn, 449 U.S. at 389, 392).

22 Fred C. Zacharias, Rethinking Confidentiality, 74 IowA L. REV. 35I, $35^{8}$ (I989).

23 United States v. Nobles, 422 U.S. 225,238 (1975).

24 For a discussion of the deceptively rights-oriented cast of the "zone of privacy" concept, see note 34 below.

25 See Hickman v. Taylor, 329 U.S. 495, 5IO-II (1947). 
and the adversary system would break down - because litigants could rely on "wits borrowed from the adversary."26

The pragmatic justifications for the two protections seem nearly identical at first glance. ${ }^{27}$ As several commentators have noted, the Supreme Court's I98I decision in Upjohn Co. v. United States ${ }^{28}$ illustrates the modern trend toward blending the two rationales. ${ }^{29}$ In Upjohn, the Court relied upon work product precedent to justify its conclusions as to the proper scope of the attorney-client privilege. ${ }^{30}$ Because the Court and others have grounded the two protections in the same rationales, the utilitarian arguments for each are vulnerable to similar critiques. ${ }^{31}$

However, the utilitarian justifications for the two protections may be more similar in form than in persuasiveness. The relative amounts of societal benefit generated by the protections are somewhat unclear due to the difficulty of gathering data on the degree to which work product immunity influences desirable trial preparation or the attorney-client privilege encourages candid lawyer-client communication, ${ }^{32}$

26 Id. at 516 (Jackson, J., concurring). Such fears grew out of the increase in the use of pretrial civil discovery that accompanied the advent of the Federal Rules of Civil Procedure in 1938. See Restatement, 1993 Draft, supra note 8, at. 1.

27 See Edward W. Cleary, Hickman v. Jencks: Jurisprudence of the Adversary System, 14 VAND. L. REV. 865, 866-67 (I96I).

28449 U.S. 383 ( 1981 ).

29 See, e.g., Marcus, supra note 3 , at $\mathrm{I}_{623-24}$.

30 See Upjohn, 449 U.S. at $39^{1-97}$. The Court used Hickman's work product rationale to explain its conclusion that the attorney-client privilege covers communications "made by Upjohn employees to counsel for Upjohn acting as such, at the direction of corporate superiors in order to secure legal advice from counsel." Id. at $394,396-97$. The Court emphasized the importance of the privilege to a lawyer's trial preparation. See id. at 390-9r (citing Hickman, 329 U.S. at 5 I i). In summation, the Court quoted Justice Jackson's famous aphorism about borrowed wits. See id, at 396 .

31 One scholar has proposed that work product immunity "be eliminated entirely." Thornburg, supra note I, at $\mathrm{I}_{5} \mathrm{I} 7$; see also id. at $\mathrm{15}_{528-29}$ (arguing that the elimination of work product immunity would have no "significant effect on a litigant's actions in preparing for trial"). Regarding the attorney-client privilege, one commentator argues that "while a preference for nondisclosure rules exists, a substantial majority of laypersons would continue to use lawyers even if secrecy were limited." Zacharias, supra note 22 , at 378 .

32 At least one commentator has speculated on the relative benefits produced by the two protections. See D. Christopher Wells, The Attorney Work Product Doctrine and Carry-Over Immunity: An Assessment of Their Justifications, 47 U. PITT. L. REV. 675, 683 (I986).

However, empirical evaluation of the benefits accruing to society from the protections is difficult and has been sporadic and incomplete. One problem is that those surveyed may feel a vested interest in bolstering the protections by overstating their value. See Alexander, supra note $I$, at I97. There are four published studies, but they are limited in scope and encompass only attorneyclient, not work product protection. These studies are at best inconclusive with respect to the utility of the attorney-client privilege and are completely uninformative with regard to the desirability of that privilege relative to work product protection.

The first study surveyed, among others, 125 lawyers and 108 laymen, see Overlap, supra note $\mathrm{I}$, at $126 \mathrm{I}, 1269$; of the laymen, only 21 had consulted a lawyer "on any sort of a regular basis," see $i d$. at 1262 , and only ro had ever consulted a lawyer regarding a litigation matter see id. 
but the two protections differ considerably in cost. For instance, work product immunity protects only materials prepared "in anticipation of litigation," whereas the attorney-client privilege attaches regardless of when the communication occurred. ${ }^{33}$ Thus, the attorney-client privilege applies to more situations, a longer time span, and probably a greater amount of material than does work product immunity. Additionally, the purportedly absolute nature of the attorney-client privilege contrasts with the built-in "need and hardship" exception to ordinary work product immunity. Thus, when the issue of waiver arises, the costs of upholding one protection may differ from the costs of upholding the other. There may therefore exist valid utilitarian reasons for distinguishing the two protections.

In addition to relying on utilitarian justifications, however, supporters of the attorney-client privilege relied in the past on non-utilitarian rationales. From this perspective, an individual's attorney-client privilege possesses a rights-based justification to which neither work

Fifty-five of the 108 laymen and 90 of the 125 lawyers indicated that the privilege encouraged communication. See id. at 1262,1270 .

A 1983 study on the corporate attorney-client privilege surveyed 85 corporate attorneys and 36 chief executive officers of companies drawn from the r981 Fortune I000 list. See Eric P. Sloter \& Anita M. Sorenson, Empirical Research Project - Corporate Legal Ethics - An Empirical Study: The Model Rules, the Code of Professional Responsibility, and Counsel's Continuing Struggle Between Theory and Practice, 8 J. Corp. L. 601, 604 nn.5-6 (I983). Twelve out of the is executives who answered the question responded that an assurance of confidentiality would make them more willing to comply with a legal investigation. See id. at 625 n.r.39.

A third study, this one from 1989 , analyzed survey results from 63 lawyers and 105 laypersons; of the non-lawyers, 32 had never consulted a lawyer. See Zacharias, supra note 22, at 379 . A majority of the laypersons stated that they would withhold information from their lawyer if the lawyer said "that he/she could not guarantee confidentiality but that, except in unusual cases, he/ she would keep information secret." Id. at 386 .

In another 1989 study on the corporate attorney-client privilege, a law professor interviewed 50 in-house corporate counsel, 52 law firm partners, and 52 corporate executives. See Alexander, supra note 1 , at 204. Forty-one of the 52 executives "indicated that they had been concerned about the applicability of privilege at least once in the past five years," id. at 242 , and 39 of the 52 thought that the privilege "serve[d] to increase management's candor with counsel," id. at 246.

If there has been little data gathered regarding the actual societal benefits of the attorneyclient privilege, even less is known with regard to work product - even the more outspoken critics of the work product doctrine are unable to point to any empirical studies on the subject. See Thornburg, supra note 1 , at $1526-38$; Wells, supra, at 683 . Because no known empirical studies have focused on the work product protection, no data exist to support distinctions between benefits arising from the incentive structures created by the two protections.

33 Because the attorney-client privilege is designed, in part, to encourage compliance with the law, its scope cannot be confined to communications made in anticipation of litigation; issues of compliance arise outside as well as inside the litigation context. 
product immunity ${ }^{34}$ nor an organization's attorney-client privilege ${ }^{35}$ can lay claim. Thus, commentators argued that confidential lawyerclient communications preserve the client's individual autonomy, ${ }^{36}$ privacy, ${ }^{37}$ and dignity and safeguard the attorney's loyalty to the client. ${ }^{38}$ The one-time popularity of these rights-based rationales ${ }^{39}$ may help to explain the lack of empirical study devoted to the benefits and costs of the privilege: supporters insisted that the personal values involved were so precious as to obviate the need to balance those values against other concerns. 40

34 The work product doctrine does implicate certain personal interests on the part of the lawyer. The Supreme Court noted in Hickman that "[e]xamination into a person's files and records, including those resulting from the professional activities of an attorney, must be judged with care. It is not without reason that various safeguards have been established to preclude unwarranted excursions into the privacy of a man's work." Hickman, 329 U.S. at 497. Similarly, the Court remarked that, without the protection, "[a]n attorney's thoughts, heretofore inviolate, would not be his own." Id. at $5 \mathrm{~m}$. However, concern for the lawyer's privacy is inseparable from concern for "the historical and the necessary way in which lawyers act within the framework of our system of jurisprudence to promote justice and to protect their clients' interests." Id. at 5ro-1I. As Justice Jackson put it, "[t]he primary effect of the practice advocated here would be on the legal profession itself. But it too often is overlooked that the lawyer and the law office are indispensable parts of our administration of justice." Id. at 514-15 (Jackson, J., concurring). Work product thus differs significantly from the individual's attorney-client privilege. The concerns for privacy in work product protection are merely concerns for ensuring the efficient administration of justice. Thus, discussions of work product have tended to focus on systemic costs and benefits to the exclusion of concerns for lawyers' privacy. The concerns for privacy in the context of the attorney-client privilege, by contrast, are personal rights-based concerns that often run counter to concerns of efficiency and accuracy in adjudication. See infra notes 37 and 40 .

35 See infra notes $41-45$ and accompanying text.

36 In his seminal article on the lawyer-client relation, Professor Fried explained:

[T]he social nexus - the web of perhaps entirely just institutions - has become so complex that without the assistance of an expert adviser an ordinary layman cannot exercise that autonomy which the system must allow him. . . . When I say the lawyer is his client's legal friend, I mean the lawyer makes his client's interests his own insofar as this is necessary to preserve and foster the client's autonomy within the law.

Charles Fried, The Lawyer as Friend: The Moral Foundations of the Lawyer-Client Relation, 85 YALE L.J. 1060, 1073 (1976).

37 "[T]here are things even more important to human liberty than accurate adjudication. One of them is the right to be left by the state unmolested in certain human relations." David W. Louisell, Confidentiality, Conformity and Confusion: Privileges in Federal Court Today, 3i TuL.

L. REV. I01, IIO (1956).

38 As Francis Bacon observed:

The greatest trust betweene man and man is the trust of giving Counsell. For in other confidences men commit the parts of life; their lands, their goods, their children, their credit, some particular affaire; but to such, as they make their Counsellours, they commit the whole: by how much the more they are obliged to all faith and integrity.

Francis Bacon, of Counsell, in The Essayes or Counsels Civill \& Morall of Francis BACON 65, 65 (Heritage Press 1944) (1597). Professor Louisell quoted this passage in defense of the attorney-client privilege. See Louisell, supra note 37 , at 112-13.

39 This focus on individual rights often appeared in general discussions of testimonial privilege. See, e.g., United States v. Bryan, 339 U.S. 323, 331 (1950).

40 See Monroe H. Freedman, Judge Frankel's Search for Truth, I23 U. PA. L. REv. 1060, 1065 (1975); see also Ronald M. DWorkin, TAKing Rights Seriously 90-94 (1977) ("It follows from the definition of a right that it cannot be outweighted by all social goals."). 
Although scholars once used a rights-based analysis to justify the individual's attorney-client privilege, few attempted to do so for corporate clients. ${ }^{41}$ Critics of a corporate attorney-client privilege note that corporations have no claim to the personal rights that underpin the attorney-client privilege. Corporations consist of people, but those people do not hold the privilege; instead, the corporation holds and has the ability to waive any privilege that would otherwise attach to communications between an employee and corporate counsel. ${ }^{42}$ Nor could a rights-based argument rest on the view that the corporation stands in the shoes of its owners. Although the corporation usually is considered a legal "person," ${ }^{43}$ it is rarely so viewed in the context of personal privacy, autonomy, and dignity. ${ }^{44}$ Any privacy interests that a corporation does possess are property interests rather than intimate personal rights. ${ }^{45}$

The inapplicability of the rights-based argument to corporations may help explain why that argument gradually sank from view. ${ }^{46} \mathrm{Un}$ til the mid-twentieth century, corporations did not usually find themselves in court. ${ }^{47}$ Thus, the attorney-client privilege originally developed as a personal privilege. However, as corporations increasingly began to litigate disputes, ${ }^{48}$ courts afforded the privilege to the corporate client as well. ${ }^{49}$ The increasing prominence of corporate liti-

41 See Alexander, supra note I, at 225. But see Fried, supra note 36, at 1075-76.

42 See Marcus, supra note 3 , at 1621 .

43 See Stephen A. Saltzburg, Corporate and Related Attorney-Client Privilege Claims: A Suggested Approach, 12 HOFSTRA L. REV. 279, 279 (r984).

${ }^{44}$ See id.; Note, The Attorney-Client Privilege: Fixed Rules, Balancing, and Constitutional Entitlement, 91 HARV. L. REV. 464, 484 (1977) [hereinafter Balancing].

45 See James A. Gardner, A Re-Evaluation of the Attorney-Client Privilege (pt. 2), 8 ViLL. L. REv. 447, 498 (1963); Elizabeth G. Thornburg, Sanctifying Secrecy: The Mythology of the Corporate Attorney-Client Privilege, 69 NOTRE DAME L. REv. 157, 185-86 (1993); Balancing, supra note 44 , at 473 .

46 See infra notes $51-55$ and accompanying text.

47 The stock-in-trade of corporate lawyers reflected the non-litigiousness of their clients. By the turn of the century, "the great corporate lawyers of the day drew their reputations more from their abilities in the conference room and facility in drafting documents than from their persuasiveness before the courts." I Robert SWAINe, The Cravath Firm and Its Predecessors, 1819-1947, at 371 (1946), quoted in Marc Galanter \& THOMAS Palay, TOURNAMENT OF LaWYers: THE TRANSFormation OF THE Big Law FirM 6 (I991).

48 As late as the early 1960s, "manufacturers avoided litigation, preferring to rely upon informal norms and sanctions to control relations with competitors, suppliers, and customers." $\mathrm{G}_{\mathrm{A}}$ LANTER \& PALAY, supra note 47 , at $5 \mathrm{I}$. The last quarter-century, however, has seen "a great surge of [corporate] litigation," fueled by "[a] business environment that is more competitive, more insecure, and more uncertain." Id.

49 See Upjohn Co. v. United States, 449 U.S. $383,389-90$ (198r) (noting that the Supreme Court "has assumed that the privilege applies when the client is a corporation") (citing United States v. Louisville \& N.R.R., 236 U.S. 318,336 (agr5)). 
gants may have changed the traditional balance between utilitarian and rights-based arguments for the attorney-client privilege. ${ }^{50}$

Whatever the causes, the former solicitude for personal rights no longer animates discussions of the attorney-client privilege. ${ }^{51}$ Instead, commentators now debate the merits of the utilitarian rationale. ${ }^{52}$ In Upjohn, the Supreme Court devoted a page-long discourse to the privilege's utilitarian basis - without ever mentioning the rights-based rationale. ${ }^{53}$ The ALI drafts address the attorney-client and work product protections almost entirely in light of utilitarian theory. ${ }^{54}$ As one court recently noted of the attorney-client privilege, "[t]he proposition is that the detriment to justice from a power to shut off inquiry to pertinent facts in court, will be outweighed by the benefits to justice (not to the client) from a franker disclosure in the lawyer's office."55

50 Some commentators maintain, on utilitarian grounds, that both work product and attorneyclient protection are less desirable in the case of corporate clients. See, e.g. Thornburg, supra note 45 , at 193 . Such considerations, however, are beyond the scope of this Note.

$51 \mathrm{Cf}$. United States v. Bilzerian, $926 \mathrm{~F} .2 \mathrm{~d} 1285,1292$ (2d Cir. I99 I) ("[T]he underlying rationale for the [attorney-client] privilege has changed over time...."). Even now, the attorney-client privilege retains a connection to rights discourse, because the privilege serves other goals that are currently accepted as personal rights, especially with regard to criminal defendants. See, e.g., United States v. Schwimmer, 892 F.2d 237, 243 (2d Cir. 1989) ("Without the attorney-client privilege, [the right to counsel] and many other rights belonging to those accused of crime would in large part be rendered meaningless."). In such instances, however, the individual's special claim to the privilege appears to spring from the underlying right, not from an inherent right to the attorney-client privilege

52 See, e.g., George A. Davidson \& William H. Voth, Waiver of the Attorney-Client Privilege, 64 OR. L. REv. 637, 638 (1986); Louis Kaplow \& Steven Shavell, Legal Advice About Information ta Present in Litigation: Its Effects and Social Desirability, I02 HARV. L. REV. 567, 613-15 (1989); Saltzburg, supra note 43 , at $282-85$.

53 See Upjohn, 449 U.S, at 389 . One could argue that the Upjohn Court emphasized utility rather than rights because the corporate privilege holder in Upjohn, in contrast to individual holders of the privilege, could not make rights arguments for the privilege. See supra p. 1703. However, the Court made clear in Upjohn that its discussion applied to the attorney-client privilege generally, as well as to corporate attorney-client privilege in particular. See Upjohn, 449 U.S. at $389-90$.

34 See RESTATEMENT, I989 Draft, supra note $7, \$$ iा $8 \mathrm{cmt}$, $c$ (addressing the attorney-client privilege); RESTATEMENT, I993 Draft, supra note $8, \$ 136 \mathrm{cmt}$ b (discussing work product protection). After devoting one and a half pages to the utilitarian rationale for the attorney-client privilege, the 1989 draft makes brief mention of "[o]ther justifications [that] can be urged for the privilege": a "fairness" concern with the provision of legal advice to those exposed to legal liability, the right to counsel, and (in language reminiscent of the Hickman line of work product precedent) "a zone of privacy within which a client may more effectively exercise . . . autonomy." REsTATEMENT, 1989 Draft, supra note $7, \$ 118 \mathrm{cmt}$. c. The draft also notes that "the privilege furthers a societal interest in protecting privacy by assuring that there are some areas into which official prying cannot reach." Id. \$ 118 reporter's note, at 82 .

55 Westinghouse Elec. Corp. v. Republic of the Philippines, 95 I F.2d r414, 1423 (3d Cir. I99I) (quoting MCCORMiCK ON EvidENCE $\$ 87$, at 204 (Edward W. Cleary ed, $2 \mathrm{~d}$ ed. 1972)) (internal quotation marks omitted) (emphasis added); see also In re Sealed Case, 877 F.2d 976 , 979 (D.C. Cir. 1989 ) ("The raison d'etre of the hallowed attorney-client privilege is the protection of a client's communications to counsel so that persons, including organizations, will be induced to consult counsel when needed."). 
The death of the rights-based arguments for the attorney-client privilege, though perhaps desirable, ${ }^{56}$ makes it necessary to reevaluate the traditional parameters of the attorney-client and work product protections. Doctrines that appeared sensible when purpose-oriented arguments were intertwined with rights arguments may no longer be persuasive when viewed solely in the light of utility. The discussion that follows focuses on three instances in which such a reexamination would prove useful.

\section{Unjustified Doctrinal Differences}

The disparate treatment that the Restatement drafts give the two protections in the areas of waiver by disclosure, shareholder litigation, and "evidence" waiver may stem from the traditional rights-oriented underpinnings of the attorney-client privilege. If both protections are now recognized to serve utilitarian goals alone, however, rights-based rationales no longer provide a principled basis for analysis.

To contemporary courts and commentators, the avowed goals of the two protections are to improve the functioning of the adversary system and, in the case of the attorney-client privilege, also to encourage compliance with complicated regulatory systems. The incentives used to achieve these goals target different entities - lawyers or clients - depending on the type of protection; a difference in the incentive systems may mean that one protection produces greater benefits than the other. The societal costs of the protections may also differ. ${ }^{57}$ Utilitarian considerations may thus provide a basis for distinguishing the two protections, but courts and commentators should be clear that any distinctions they draw stem from utility, not from an inadvertent perpetuation of rights discourse.

Although the modern consensus is that the protections should be viewed in relation to their social purposes, courts also have articulated concerns of fairness to the party seeking disclosure, especially in the waiver context. See, e.g., Permian Corp. v. United States, 665 F.2d 1214, 122I (D.C. Cir. 1981); Byrnes v. IDS Realty Trust, 85 F.R.D. 679,688 (S.D.N.Y. 1980). The emphasis on fairness to the other side contrasts with the former focus on fairness to - or rights of - the privilege holder and can be seen as linked to the systemic concern for producing just outcomes.

56 See Thornburg, supra note 45 , at 182 (criticizing as "[p]rivacy and [r]elationship [m]yths . .. the belief that courts should not compel revelation of attorney-client confidences"); Zacharias, supra note 22 , at 367 n.73 ("Despite the rhetoric in commentaries, lawyers are not unique in their relationship to clients...." (citation omitted)); id at 368 (observing that the "dignity" argument "applies to all professions"); id. at 369 (arguing that "the lawyer who contributes to the notion that the client can get away with anything demeans the client as a moral individual"); Balancing, supra note 44 , at 482 ("To impose restrictions simply on the process by which individuals learn of their rights is no different from the countless qualifications attached for utilitarian purposes to the full exercise of other rights in society."); $i d$. at 483 ("Friends and lovers . . . are surely at least as intimate in their interactions as an attorney and his client.").

5) See supra notes $32-33$ and accompanying text. 


\section{A. Waiver by Disclosure}

In accord with long-established tradition, ${ }^{58}$ the ALI draft provides that " $t]$ he attorney-client privilege . . . is waived if the client, the client's lawyer, or another authorized agent of the client substantially discloses the communication in a non-privileged communication." 59 Work product, by contrast, is waived by disclosure only if "a party entitled to assert the immunity or the party's lawyer or other authorized representative... [d]iscloses the material to third persons in circumstances in which there is a significant likelihood that an adversary or potential adversary will obtain it." 60 The disparity between the two standards for waiver traditionally has been explained with a nominally purpose-oriented argument. The removal of the rights-based mystique from the attorney-client privilege, however, should prompt a reevaluation of that argument.

The ALI draft explains the draconian sweep of the disclosure waiver of the attorney-client privilege by asserting that such disclosure "is inconsistent with a claim that the client does not wish the communication disclosed"; indeed, it observes that disclosure to a non-privileged party may in some circumstances "indicate that the client did not originally contemplate confidentiality." ${ }^{11}$ This contention begs the question of the value to the adversary system of total - as opposed to situational - confidentiality. The rationale for the privilege is to encourage full and frank disclosure by clients of facts that may assist their lawyers in giving the best possible legal advice. Clients will not make such disclosure, the argument goes, unless they are assured that their confidences will go no further than their lawyers. Although current studies of the question have proved inconclusive, ${ }^{62}$ common sense dictates that at least some clients will hesitate to disclose some material facts absent an assurance that the disclosures will not be passed along to their adversaries. There is a sharp distinction, however, between wishing to keep facts from one's adversary and wishing to keep them from the entire world. Under a utilitarian analysis, the privilege is justified only to the extent that it maximizes the efficiency of the lawyer-client relationship. The privilege induces clients to be frank

58 See, e.g., United States v. United Shoe Mach. Corp., 89 F. Supp. 357, 358-59 (D. Mass. 1950).

59 RestatemenT, 1989 Draft, supra note 7 , ई 129.

60 Restatement, i99.3 Draft, supra note 8 , \$ 140 (emphasis added); see also Stix Prod., Inc. v. United Merchants \& Mfrs., Inc., 47 F.R.D. 334, 338 (S.D.N.Y. 1969) ("The work-product privilege should not be deemed waived unless the disclosure is inconsistent with maintaining secrecy from possible adversaries. ${ }^{m}$.

61 Restatement, 1989 Draft, supra note $7, \$ 129 \mathrm{cmt}$. b; see also In re Auclair, 961 F.2d 65, 69 (5th Cir. 1992) (observing that disclosure to a third person "eliminates the intent for confidentiality on which the privilege rests").

62 See supra note 32 . 
with their lawyers by promising protection from adversaries, not from the rest of the planet. ${ }^{63}$

In contrast to the systemic benefits that now constitute the accepted justification for the attorney-client privilege, both the rhetoric and substance of the "waiver by disclosure" doctrine betray the continued influence of the rights-based argument. A representative exam$\mathrm{ple}^{64}$ is Judge Friendly's explanation of how a client had waived his privilege by disclosure to his accountant in In re Horowitz. ${ }^{65}$ Judge Friendly began with the "basic principle[ ]" that "[t]he privilege finds its justification in the need to allow a client to place in his lawyer the 'unrestricted and unbounded confidence' that is viewed as essential to the protection of his legal rights." 66 . This description is typical in its evocation of the sanctity and absolute nature of the attorney-client relationship. Judge Friendly concluded that "[i]t is not asking too much to insist that if a client wishes to preserve the privilege under such circumstances, he must take some affirmative action to preserve confidentiality" by not allowing a third party to gain access to the communications. ${ }^{67}$ Ironically, this view of the attorney-client relationship as sacrosanct actually limits protection, because it leads to an unduly high standard of client conduct for the preservation of confidentiality. It requires the client to justify the privilege as though it were truly invoked against the world as a whole, rather than specifically against the client's adversary. ${ }^{68}$

A second example of rights-oriented reasoning is the argument that the disclosure waiver should apply differently to the two protections, because the attorney-client privilege exists "to protect the attorney-client relationship," whereas the work product doctrine exists "to promote the adversary system." ${ }^{n 9}$ If no dispositive values inhere in the

\footnotetext{
63 See Marcus, supra note 3 , at 1625.

64 Others abound. See, e.g., United States v. American Tel. and Tel. Co., 642 F.2d I285, 1299 (D.C. Cir. 1980).

65482 F.2d 72 (2d Cir. 1973).

66 Id. at 81 (citation omitted).

67 ld. at 82 .

68 See Weil Ceramics \& Glass, Inc. v. Work, no F.R.D. 500,502 (E.D.N.Y. 1986) ("The attorney-client privilege is a narrower privilege precisely because its protection is absolute. Any breach of confidentiality between attorney and client, with limited exceptions, constitutes a waiver.").

69 United States v. American Tel. \& Tel. Co., 642 F.2d I285, I299 (D.C. Cir. 1980) (emphasis omitted).

Similarly, the Third Circuit has justified distinctions with regard to the disclosure waiver by claiming that the attorney-client privilege, in contrast to work product protection, exercises only an indirect influence over the functioning of the legal system. See Westinghouse Elec. Corp. v. Republic of the Philippines, 95 $\mathrm{F} .2 \mathrm{~d} \mathrm{I} 4 \mathrm{I}_{4},{ }_{4} 28$ (3d Cir. 199r). The court in Westinghouse failed to articulate completely why the influence of the attorney-client privilege on the legal system was less "direct" than that of the work product doctrine, but the court's phraseology suggests the view that the attorney-client privilege exists, first and foremost, to "promote[] the attorney-client relationship." Id. In the absence of a rights-based rationale for the privilege, however, this reasoning
} 
attorney-client relationship, however, the relationship is valuable only as a means to improve the legal system - valuable, in other words, for the same reason as the work product protection.

The modern consensus is that the attorney-client privilege seeks to further the adversary system by facilitating the best possible advocacy. Thus, the ALI's discussion of work product disclosure applies equally to the attorney-client privilege:

Effective trial preparation may entail sharing work product with coparties and nonparties. Work product, including work product of a lawyer, therefore may generally be shared freely among the client, the client's lawyer or other representative, associated lawyers and other professionals working on the matter in the interest of the client, actual or potential coparties, or a client's business advisers or agents. Such sharing is consistent with the objective of fostering effective pretrial preparation and with maintaining privacy against an adversary, ${ }^{70}$

The applicability of this rationale to the attorney-client privilege is already recognized to some extent in the "joint defense" or "common interest" exception to the waiver by disclosure. Currently, the attorney-client privilege may persist despite disclosure to certain third parties, because courts recognize "[t]he need to protect the free flow of information from client to attorney ... whenever multiple clients share a common interest about a legal matter." 11 However, in order for a common interest to preserve the privilege despite disclosure, courts require "that the nature of the interest [shared with the third party] be identical, not similar, and be legal, not solely commercial." This limitation conflicts with the utilitarian insight that the benefits of the protection stem from the actions of a person whose concern is maintaining privacy from his adversary, rather than the world at

mistakes the means for the end; directness of effect is not the main concern of the utilitarian perspective. See Hickman v. Taylor, 329 U.S. 495, 514-15 (1947) (Jackson, J., concurring). Without a rights-based foundation, the Westinghouse court's distinction between the attorney-client and work product protections collapses.

70 Restatement, 1993 Draft, supra note $8, \$ 140 \mathrm{cmt}$. e.

71 United States v. Schwimmer, 892 F.zd 237, 243-44 (2d Cir. r989) (quoting Daniel J. Capra, The Attorney-Client Privilege in Common Representations, 20 TRIAL LAw. Q., Summer 1989, at 20, 2I) (internal quotation marks omitted).

72 Duplan Corp, v. Deering Milliken, Inc., 397 F. Supp. II46, 1172 (D.S.C. 1974); see also In re Auclair, 961 F.2 65, 69 (5th Cir. 1992) (stating that the privilege is not waived if the "communication is shared with a third person who has a common legal interest" (quoting Hodges, Grant \& Kaufman v. United States Government, 768 F.2d 719, 721 (5th Cir. 1985))). Duplan defines a shared "legal interest" as a "duty or direct transaction between the two clients of the attorney." Duplan, 397 F. Supp. at II 75; see also Weil Ceramics, I10 F.R.D. at 503 (limiting the community of interest rule to situations involving legal duties to defend or "client transaction[s] between two separate entities which are represented by the same attorney").

The common interest exception to waiver of the privilege has engendered an intricate body of case law on the question of precisely what kinds of parties share the requisite commonality of interest. See, e.g., In re Grand Jury Subpoenas, 902 F.2d 244, 249 (4th Cir. I990); Bauman v. Jacobs Suchard, 136 F.R.D. 460, 461-62 (N.D. Ill. 1990); In re Grand Jury Subpoena Duces Tecum Dated November 16, 1974, 406 F. Supp. 381, 389 (S.D.N.Y. 1975). 
large. The likely parity of incentives (and thus of benefits) supports the protection of attorney-client communications, like work product, unless the disclosure increased the likelihood that an adversary would obtain the protected material. A utilitarian analysis, however, must look to costs as well as benefits. Because the attorney-client privilege covers more material over a longer period of time and is more durable than work product immunity, courts may consider that a narrower construction of waiver of the attorney-client privilege would deprive parties and tribunals of too much relevant information. ${ }^{73}$. Such a utilitarian distinction may be legitimate - but the invocation of rights discourse should not suffice.

\section{B. Shareholder Litigation}

Shareholder litigation is another area in which attorney-client communications enjoy less protection than do work product materials. As in the case of waiver by disclosure, the discrepancy seems to stem in part from the vestigial influence of rights discourse.

The ALI's proposed exception to the attorney-client privilege in shareholder litigation against organizational fiduciaries rests on the well-known decision in Garner $v$. Wolfinbarger, ${ }^{74}$ in which the Fifth Circuit held that shareholder plaintiffs could discover otherwise privileged communications between corporate defendants and their counsel upon a showing of cause, ${ }^{75}$ Following Garner's lead, the ALI draft nullifies the attorney-client privilege in a proceeding that involves a dispute between an "organizational client" and its constituents if officers or directors are charged with a breach of fiduciary duties, the communication occurred prior to the suit and is directly relevant, and the tribunal makes a finding of need and appropriateness. ${ }^{76}$

However, the ALI suggests no comparable exception to the work product protection. ${ }^{77}$ This omission cannot reflect an absence of need: in shareholder litigation, materials protected as work product may well prove to be equally as important as communications protected under the attorney-client privilege. ${ }^{78}$ Nor can the omission stem from the built-in exception to work product protection activated upon a showing of substantial need and undue hardship; such a showing, though it

73 Courts may also feel relatively comfortable with waiver by disclosure, because the waiver generally depends on a voluntary act of the privilege holder. The holder's volition, though no longer relevant to show a relinquishment of the holder's "rights," may indicate that clients" incentives would be relatively unaffected by a finding of waiver. By contrast, a waiver doctrine that ignores the actions of the holder may significantly distort clients' and lawyers' incentives. See infra p. 1712 .

74430 F.2d 1093 (5th Cir. I970), cert, denied, 40 I U.S. 974 (1971).

75 See id, at $\mathrm{I}_{103-04}$.

76 See Restatement, 1989 Draft, supra note $7, \$ 134$.

77 See Restatement, I993 Draft, supra note 8.

78 See, e.g., Donovan v. Fitzsimmons, 90 F.R.D. 583,588 (N.D. Ill. I 981 ). 
would justify the production of ordinary work product, would leave opinion work product absolutely protected even though the latter might be extremely useful to shareholder plaintiffs.

The courts that accept Garner but refuse to apply it to work product have not advanced a compelling rationale. For example, in Donovan $v$. Fitzsimmons ${ }^{79}$ the court explained its refusal thus:

The Garner rule forecloses the use of the attorney-client privilege, itself intended for the ultimate benefit of the client, to prevent disclosure of a breach of the client's trust. Shareholders or beneficiaries, however, do not stand in the same position with respect to the attorney, for whom the work-product rule is designed to benefit, as they do to their own trustees. ${ }^{80}$

There are at least two flaws in this argument. First, even if the court's focus on the intended beneficiaries of the protection is apposite, it fails to identify those beneficiaries correctly. Garner's recognition that a corporation's "management has duties which run to the benefit ultimately of the stockholders" 81 means that the attorney-client privilege, to the extent that it benefits anyone aside from society at large, ultimately benefits the shareholders. ${ }^{82}$ Similarly, the work product rule, by improving the conditions under which the attorney works, benefits the attorney primarily to benefit the client and, through the client, the adversary system..$^{83}$ Of course, the issue of who the client really is complicates this question. Arguably, when work product is prepared in anticipation of litigation between the corporation and its shareholders, the shareholders can no longer be considered to have a sufficient mutuality of interest to qualify as clients of the corporate counsel. $^{84}$ This argument, however, applies equally to the attorneyclient privilege, because once the shareholders' interests become adverse to the corporation's, the shareholders may no longer be considered to hold the privilege. ${ }^{85}$ On the other hand, Garner provides that, leaving aside the question whether the shareholders participate in the attorney-client relationship, the fiduciary relationship entitles share-

$79.1 d$.

80 Id. at $587-88$.

81 Garner v. Wolfinbarger, 430 F.2d 1093, 1101 (5th Cir. 1970), cert. denied, 40I U.S. 974 (1971).

82 As the court argued in Garner:

The representative and the represented have a mutuality of interest in the representative's freely seeking advice when needed and putting it to use when received. ... [M]anagement judgment must stand on its merits, not behind an ironclad veil of secrecy which under all circumstances preserves it from being questioned by those for whom it is, at least in part, exercised.

Id.

83 Attorneys cannot legitimately claim a proprietary interest in their work product, especially because they are paid for their services, See. Thornburg, supra note I, at 1544 .

84 See In re International Sys. \& Controls Corp. Sec. Litig., 693 F.2d 1235, 1239 (5th Cir. 1982).

85 See Model Rules of Professional Conduct Rule r.i3 (I994). 
holders in some instances to pierce protections intended to benefit the corporation. This insight should apply, to the extent it applies at all, to work product as well as the attorney-client privilege. Additionally, although the mutuality of interest argument is more persuasive than a bald statement that work product inures to the benefit of the lawyer rather than the client, the argument does not address instances in which work product is prepared in anticipation of litigation between the corporation and non-shareholders. ${ }^{86}$

Second, the Donovan court's assumption that the intended benefits inure primarily to either the client or the lawyer ignores the modern shift from a rights-based to a utilitarian view of the work product and attorney-client protections. In light of the fact that both protections find their justifications in their effect on the legal system, any benefit to the individual parties is important, not as an end in itself, but merely for the incentives it creates to promote systemic goals. In this regard, the question who "benefits" is relevant only if the incentive effect arising from a protection works differently for clients' decisions to communicate with their lawyers than it does for lawyers' decisions to prepare for trial.

Perhaps courts' reluctance to extend Garner to work product protection indicates a discomfort with Garner itself. ${ }^{87}$ If so, the ALI should perhaps reconsider the merits of Garner. If, instead, the restriction of Garner to the attorney-client privilege stems from underlying utilitarian concerns, courts should substitute an explicit utilitarian calculus for rights-oriented rhetoric.

\section{C. "Evidence" Waiver}

The ALI drafters' concept of waiver encompasses both knowing, or voluntary, waiver and also (irrespective of intent or state of mind) certain other conduct by the privilege holder. ${ }^{88}$ In the case of work product, however, the drafters, in effect, extend the waiver to situations involving no act at all on the part of the client by allowing the party seeking discovery the ability to trigger a "work product as evi-

86 Work product prepared for prior, unrelated litigation seems likely to comprise a significant amount of the work product sought by plaintiffs in shareholder litigation, because the status of such work product is frequently litigated and because most courts will protect such work product in subsequent litigation. See Special Project, The Work Product Doctrine, 68 Cornell L. REv. 760,855 n. 581,856 ( 1983 ).

87 Although most jurisdictions that have considered the issue tend to follow Garner, see, e.g., Fausek v. White, 965 F.2d I26, 130 (6th Cir.), cert. denied, 113 S, Ct. 814 (1992), other jurisdictions do not, see, e.g., Shirvani v. Capital Investing Corp., i12 F.R.D. 389, 390-91 (D. Conn. I986), cited in Bradford D. Bimson, Note, Zirn v. VLI Corp.: The Far-Reaching Implications of Loquacity, r9 DEL. J. CoRP. L. 1067 , 1086 n.126 (1994); Dickerson v. Superior Court, 185 Cal. Rptr. 97, 99 (Ct. App. 1982).

88 See Restatement, 1989 Draft, supra note 7 , Title C introductory note, at 198 . The drafters' lack of emphasis on voluntariness and knowledge accords in some ways with the conception of the privilege as proceeding from a strictly utilitarian standpoint. 
dence" waiver. Both an analysis of case law and a comparison with the attorney-client privilege argue against the recognition of such a waiver,

The ALI's "evidence" waiver dramatically expands traditional waiver doctrine. ${ }^{89}$ In section I4IA, entitled "Work Product as Evidence," the ALI draft provides simply that "[w]ork product that constitutes direct and substantial evidence of a material issue before a tribunal is subject to disclosure by order of the tribunal when access is required for a fair trial of the issue." ${ }^{\text {"9o }}$ Unlike other waiver provisions, ${ }^{91}$ section I4IA contains no limitations on the type of subject matter that could trigger the waiver. Although the section cites a somewhat narrow range of cases - all of which involve questions of the knowledge or state of mind of the holder of the protection - the majority of hotly contested materials may fall precisely within this range. ${ }^{92}$ Even more important, section I4 IA allows a waiver in the absence of any action by the holder of the protection. As the Comment notes:

[L] oss of the immunity under $\S \mathrm{I} 4 \mathrm{IA}$ is created by action of the party seeking the otherwise protected material. The difference in strategic positions of the holder and the opponent of immunity justifies stricter scope to loss of immunity under this Section, which deals with initiatives taken by the opponent. ${ }^{93}$

Perhaps for this reason, the commentary to section I4IA warns that " $[t]$ he disclosure ordered should be no greater than required for the purpose." ${ }^{94}$

A problem with the ALI's evidence waiver is that the draft cites only ten cases, only two of which appear to use an analysis similar to

89 "Work product as evidence" waiver is one of a larger set of waivers that could be generally termed "at issue" waivers. A prime example of an at issue waiver is the waiver based on a client's assertion of advice of counsel - a waiver that the courts and the ALI agree should extend to both kinds of protection. The ALI's tentative draft contains an exception to the attorney-client privilege in cases in which the client asserts "as to a material issue in a proceeding that: (a) The client acted upon the advice of a lawyer or that the advice was otherwise relevant to the legal significance of the client's conduct; or (b) A lawyer's assistance was ineffective, negligent, or for some other reason wrongful." Restatement, r 989 Draft, supra note $7, \&$ I $30(\mathrm{r})$. The work product draft contains a substantially șimilar waiver provision. See ReșraTEMENT, I993 Draft, supra note $8, \$ \mathrm{I} 4 \mathrm{I}(4)$. A notable example in the context of the attorney-client privilege is United States v. Bilzerian, 926 F.2d I285, I292-94 (2d Cir. I991).

90 Restatement, i993 Draft, supra note 8, § I4IA.

91 See, for instance, the advice of counsel waiver, discussed above in note 89 .

92 Indeed, the material at stake in a case involving the evidence waiver will, by definition, be hotly contested and important, because to qualify for the waiver, the material must be both "direct and substantial evidence of a material issue" and "required for a fair trial." RESTATEMENT, I993 Draft, supra note $8, \$ 14 \mathrm{IA}$. Some have criticized the evidence waiver's emphasis on the relevance or importance of the material to the issues in the case as running counter to the goals of the protections. See infra note 102 and accompanying text.

93 Restatement, 1993 Draft, supra note 8 , \$ I4IA cmt. b.

94 Id. $\mathrm{cmt}$. c. 
the ALI's. Despite the draft's explanation that "[t]he [I4IA] exception reflects a balance somewhat different than the exception for need and hardship" for ordinary work product, ${ }^{95}$ none of the ten cases cited in the Reporter's Note to section I4IA appear to use a "work product as evidence" analysis as such. Instead, each court stated or implied that the party seeking disclosure of work product must show "substantial need" and "undue hardship." 96 One of the two cases that came somewhat closer to the ALI's formulation of evidence waiver, Donovan v. Fitzsimmons, ${ }^{97}$ held that, because the protected materials were directly at issue, "circumstances . . . warrant[ed] the presumptive application" of the need and hardship exception. ${ }^{98}$ A second court, in In re Sunrise Securities Litigation, ${ }^{99}$ attempted a further break from the undue hardship aspect of the traditional need and hardship analysis by arguing that, when the work product is directly at issue, "a party is not required to prove that information cannot be discovered by any method other than document production." 100 The court supported this argument, however, with language redolent of undue hardship analysis by claiming that "contemporaneous records have "an inherent reliability which cannot now be duplicated by any other source of evidence." "101

A comparison of work product to the attorney-client privilege argues against the evidence waiver. Critics claim that the evidence waiver in the attorney-client context would detrimentally affect the creation of protected material - material that is desirable because its existence reflects communications that further the goals of the legal system. With the substitution of the lawyer's incentives for those of the client, the same arguments apply equally well to work product doctrine. As one court noted of the attorney-client privilege:

$[F]$ inding that confidentiality may be waived depending on the relevance of the communication completely undermines the interest to be served. Clients will face the greatest risk of disclosure for what may be the most important matters. Furthermore, because the definition of what may be

\section{Id. cmt. a.}

96 See Holmgren v. State Farm Mut. Auto. Ins. Co., 976 F.2d 573,577 (9th Cir. I992); In re International Sys. \& Controls Corp. Sec. Litig., 693 F.2d 1235, 1240-41 (5th Cir. 1982); Bio-Rad Lab., Inc. v. Pharmacia, Inc., 130 F.R.D. I16, 121 (N.D. Cal. I990); In re Sunrise Sec. Litig., 130 F.R.D. 560,568 \& n.24 (E.D. Pa. I989); Charlotte Motor Speedway, Inc. v. International Ins. Co., I25 F.R.D. 127 , I3I (M.D.N.C. I989); Donovan v. Filzsimmons, 9o F.R.D. 583, 588 (N.D. IIl. 1981); APL Corp. v. Aetna Cas. \& Sur. Co., 91 F.R.D. 10, 14 (D. Md. 1980); Handgards, Inc. v. Johnson \& Johnson, 413 F. Supp. 926, 931 (N.D. Cal. I976); SEC v. National Student Mktg. Corp., 18 Fed. R. Serv, 2d (Callaghan) 1302, 1305, 1311 (D.D.C. 1974); Bird v. Penn Cent. Co., 61 F.R.D. 43,46 (E.D. Pa, I973).

97 9o F.R.D. 583 (N.D. Ill. I98I).

98 Id. at 588 .

99130 F.R.D. 560 (E.D. Pa. 1989 ).

$100 \mathrm{Id}$. at 568 .

101 Id. at 568 n.24 (quoting In re Hawaii Corp., 88 F.R.D. 518,525 (D. Haw. I980)). 
relevant and discoverable from those consultations may depend on the facts and circumstances of as yet unfiled litigation, the client will have no sense of whether the communication may be relevant to some future issue, and will have no sense of certainty or assurance that the communication will remain confidential. ${ }^{102}$

This fear that the most important matters may also be the least protected is as likely to inhibit lawyer preparation as it is to chill client communication. Moreover, uncertainty as to the posture of future litigation will afflict lawyers as well as clients: not even an experienced practitioner can always predict the strategies of an adversary or the rulings of a court. Unless the costs of work product protection are found to be greater than those of the attorney-client privilege, ${ }^{103}$ the same incentive-oriented analysis that leads courts to refuse to apply an evidence waiver to attorney-client privilege should militate against a finding of the "work product as evidence" waiver. ${ }^{104}$

\section{CONClusion}

The rights-based arguments for the attorney-client privilege were perhaps never more than rhetorically persuasive. Courts, however, have often relied on such arguments to bolster their conclusions about the proper scope of the privilege. In the context of waiver, many courts base distinctions between the attorney-client and work product protections on assumptions drawn from rights discourse. The distinctions themselves may prove legitimate - but they should only be accepted as such after a rigorous and purely utilitarian analysis.

102 Rhone-Poulenc Rorer Inc. v. Home Indem. Co., 32 F.3d 851, 864 (3d Cir. r994). Although its critique raises important questions, the Rhone-Poulenc court failed to note that the importance of the material cuts both ways in the cost-benefit analysis. Although an evidence waiver for important material may reduce the incentives of lawyers and clients to engage in desirable communication or trial preparation, it will probably not completely curtail these activities. Assuming that litigants and lawyers continue to create some otherwise protected material, the waiver will benefit the legal system by providing factfinders with important information.

103 Such a result seems unlíkely, See supra p. I70r.

104 In fact, courts have considered evidence waiver with regard to both protections, not just with regard to work product. See, e.g., National Indus. Transformers, Inc. v. Atlantic Mut. Ins. Co., No. 9r Civ. 7192, 1993 WL 158373 , at *4 (S.D.N.Y. May 11, 1993) (refusing to find an evidence waiver of attorney-client and work product material); Leucadia, Inc. v. Reliance Ins. Co., ror F.R.D. 674, 679 (S.D.N.Y. 1983) (refusing to find an evidence waiver of attorney-client material). 